UDK 577.1 : 61

ISSN 1452-8258

J Med Biochem 41: 204-210, 2022

\title{
ASSOCIATION OF KLOTHO GENE POLYMORPHISM WITH CEREBRAL INFARCTION
}

\author{
VEZA POLIMORFIZMA KLOTHO GENA SA CEREBRALNIM INFARKTOM \\ Yu $\mathrm{Li}^{1}$, Qiang Zhang ${ }^{2}$, Haiping Bao ${ }^{1}$, Chen $\mathrm{Nie}^{1}$ \\ ${ }^{1}$ Department of Neurology, The Second Affiliated Hospital of Dalian Medical University, Dalian, China \\ ${ }^{2}$ Department of Rehabilitation Medicine, Dalian Shipyard Rehabilitation Hospital, Dalian, China
}

\section{Summary}

Background: We aimed to investigate the expression of Klotho gene in peripheral blood of patients with cerebral infarction $(\mathrm{Cl})$ and the association of its polymorphisms with the occurrence of $\mathrm{Cl}$.

Methods: A total of $60 \mathrm{Cl}$ patients ( $\mathrm{Cl}$ group) and 20 healthy people receiving physical examination (control group) were enrolled as the research subjects. The expression of Klotho gene in $\mathrm{Cl}$ group and control group was determined using enzyme-linked immunosorbent assay kit. Single nucleotide polymorphisms (rs192031, rs200131 and rs102312) in the promoter region of the Klotho gene were typed via conformational difference gel electrophoresis. Besides, whether the distribution frequencies of Klotho genotypes conformed to Hardy-Weinberg equilibrium was evaluated by chi-square test. Meanwhile, the associations of Klotho alleles and gene polymorphisms with $\mathrm{Cl}$ occurrence were analyzed.

Results: The protein expression level of Klotho in the peripheral blood was remarkably lower in patients in $\mathrm{Cl}$ group than that in control group $(\mathrm{P}<0.05)$. HardyWeinberg equilibrium analysis revealed that Klotho gene polymorphisms (rs192031, rs200131 and rs102312) conformed to the genetic equilibrium distribution ( $P>0.05)$. Gene-based association analysis manifested that only rs192031 polymorphism and alleles were correlated with $\mathrm{Cl}$ occurrence $(\mathrm{P}<0.05)$. Systolic blood pressure and highdensity lipoprotein cholesterol were notably higher in $\mathrm{Cl}$ patients with TT genotype of Klotho gene polymorphism rs192031 than those in control group $(P<0.05)$.

\section{Kratak sadržaj}

Uvod: Cilj nam je bio da istražimo ekspresiju Klotho gena u perifernoj krvi pacijenata sa cerebralnim infarktom $(\mathrm{Cl})$ i povezanost njegovih polimorfizama sa pojavom $\mathrm{Cl}$.

Metode: Ukupno 60 pacijenata sa $\mathrm{Cl}$ (Cl grupa) i 20 zdravih osoba na fizikalnom pregledu (kontrolna grupa) upisano je kao subjekti istraživanja. Ekspresija Klotho gena u Cl grupi i kontrolnoj grupi je određena korišćenjem kompleta za enzimski imunosorbentni test. Polimorfizmi pojedinačnih nukleotida (rs192031, rs200131 i rs102312) u promotorskom regionu Klotho gena su tipizovani putem konformacione razlike u gel elektroforezi. Osim toga, da li su frekvencije distribucije Klotho genotipova u skladu sa Hardy-Weinbergovom ravnotežom procenjeno je hi-kvadrat testom. U međuvremenu, analizirane su asocijacije Klotho alela i polimorfizama gena sa pojavom $\mathrm{Cl}$.

Rezultati: Nivo ekspresije proteina Klotho-a u perifernoj krvi bio je značajno niži kod pacijenata u $\mathrm{Cl}$ grupi nego u kontrolnoj grupi $(P<0,05)$. Hardy-Weinbergova analiza ravnoteže otkrila je da se polimorfizmi Klotho gena (rs192031, rs200131 i rs102312) podudaraju sa distribucija genetičke ravnoteže $(P>0,05)$. Analiza asocijacije zasnovana na genima pokazala je da su samo rs192031 polimorfizam i aleli u korelaciji sa pojavom $\mathrm{Cl}(\mathrm{P}<0,05)$. Sistolni krvni pritisak i holesterol lipoproteina visoke gustine bili su značajno viši kod pacijenata sa $\mathrm{Cl}$ sa TT genotipom polimorfizma Klotho gena rs192031 od onih u kontrolnoj grupi $(P<0,05)$. Štaviše, nije bilo asocijacija rs200131 i rs102312 polimorfizama i alela sa pojavom $\mathrm{Cl}(\mathrm{P}>0,05)$.

Address for correspondence:

Chen Nie, MM

Department of Neurology, The Second Affiliated Hospital of

Dalian Medical University, 467 Zhongshan Road, Shahekou

District, Dalian, Liaoning 116000, China

Tel: +86017709876867

e-mail: niechen216789@126.com 
Furthermore, there were no associations of rs200131 and rs102312 polymorphisms and alleles with the occurrence of $\mathrm{Cl}(\mathrm{P}>0.05)$.

Conclusions: The expression level of Klotho is evidently reduced in the peripheral blood of $\mathrm{Cl}$ patients. Rs192031 in the promoter region of the Klotho gene is associated with the occurrence of $\mathrm{Cl}$, while rs200131 and rs102312 have no relations with $\mathrm{Cl}$.

Keywords: Klotho, cerebral infarction, polymorphism

\section{Introduction}

Cerebral infarction $(\mathrm{Cl})$ is an ischemic-hypoxic necrosis induced by insufficient blood supply to local brain tissues. It is characterized by high incidence and disability rates. Various factors can lead to the occurrence of $\mathrm{Cl}$, the main cause of which is cerebral atherosclerosis (1). The nature of atherosclerosis lies in the chronic activation of endothelial cells caused by inflammatory and fibro proliferative reactions, which can induce vascular stenosis and insufficient blood supply to the brain, and the secondary rupture of fibrous cap in atherosclerotic plaque eventually leads to $\mathrm{Cl}(2,3)$. The correlation of genetic factors (especially gene polymorphisms) with acute atherosclerotic $\mathrm{Cl}$ has become a research hotspot in recent years. Cathepsin S (CTSS), a cysteine protease of the papain superfamily, plays a vital role in the degradation and reconstruction of extracellular matrix, antigen presentation, inflammation, immunity and angiogenesis (4). A study revealed that single nucleotide polymorphisms (SNPs) (rs774320676 and rs928508030) of the CTSS gene are related to the risk of acute atherosclerotic $\mathrm{Cl}$. The T allele of rs774320676 and the $\mathrm{G}$ allele of rs928508030 of CTSS are genetic susceptibility genes for acute atherosclerotic $\mathrm{Cl}$ (5).

Klotho, as an anti-aging gene, is able to reduce oxidative stress, thus protecting the cardio-cerebrovascular system (6). A study indicated that the elevated plasma Klotho concentration in patients with acute ischemic stroke is correlated with a good functional prognosis (7). Basic experiment illuminated that Klotho is an inducer of metabolic coupling between neurons and astrocytes. Klotho can be released by the neuronal glutamatergic activity and insulin regulation, thereby stimulating the formation and release of lactic acid in astrocytes (8). Traditional Chinese medicine ligustilide is capable of ameliorating cerebral ischemia-reperfusion injury in mice by up-regulating Klotho expression (9). However, the association of Klotho gene polymorphism with $\mathrm{Cl}$ has not been reported yet.

The distribution of polymorphisms (rs192031, rs200131 and rs102312) in the promoter region of the Klotho gene was determined in $\mathrm{Cl}$ patients in this study, so as to provide a certain reference for further research of the genetic pathogenesis of $\mathrm{Cl}$.
Zaključak: Nivo ekspresije Klotho-a je evidentno smanjen u perifernoj krvi pacijenata sa Cl. Rs192031 u promotorskom regionu Klotho gena je povezan sa pojavom $\mathrm{Cl}$, dok rs200131 i rs102312 nemaju veze sa $\mathrm{Cl}$.

Ključne reči: Klotho, cerebralni infarkt, polimorfizam

\section{Materials and Methods}

\section{Subjects}

A total of $60 \mathrm{Cl}$ patients admitted to our hospital from January 2016 to January 2019 were enrolled as the research subjects, including 31 males and 29 females aged $(57.41 \pm 2.34)$ years old. About $4 \mathrm{~mL}$ of venous blood was extracted, anticoagulated with sodium citrate, and stored in a refrigerator at $-20{ }^{\circ} \mathrm{C}$. Meanwhile, 20 healthy people receiving physical examination were selected as the controls, with 10 males and 10 females aged $(57.13 \pm 2.19)$ years old. This study was approved by the Ethics Committee of Linyi Central Hospital, and all the participants signed the informed consent. The patients in the $\mathrm{Cl}$ group met the diagnostic criteria of the Chinese Guidelines for Diagnosis and Treatment of Acute Ischemic Stroke 2019, without transient ischemic attack, and the diagnosis was confirmed by imaging examinations. The subjects in the control group were healthy people who underwent routine physical examination in our hospital, without a history of cardiovascular and cerebrovascular diseases and related family history.

\section{Detection of serum Klotho protein}

About $4 \mathrm{~mL}$ of venous blood was collected and anticoagulated with sodium citrate to detect serum Klotho protein using an enzyme-linked immunosorbent assay (ELISA) kit (Sigma-Aldrich, St. Louis, MO, USA) in accordance with the instructions.

\section{Deoxyribonucleic acid (DNA) extraction}

A total of $4 \mathrm{~mL}$ of patient's EDTA-anticoagulated blood was taken to extract genomic DNA according to the instructions of the DNA Extraction Kit (Guge Bio-Technology Co., Ltd., Wuhan, China). Subsequently, the quality of $2 \mu \mathrm{L}$ of sample was measured in $1.5 \%$ agarose gel electrophoresis. Meanwhile, the concentration of the extracted DNA was determined using an ultraviolet spectrophotometer.

\section{Polymerase chain reaction (PCR) amplification}

Primers were designed to amplify Klotho gene polymorphismsrs192031, rs200131 and rs102312. 
Table I Primer sequences and product sizes of different polymorphisms in the promoter region of the Klotho gene.

\begin{tabular}{|l|l|l|}
\hline Polymorphism & Primer sequence $\left(5^{\prime}-3^{\prime}\right)$ & Product (bp) \\
\hline rs192031 & Forward: AGCTGATGGCTATCGTAGCGACCReverse: TGGGCTAGCTAGCTAGTCGG & 223 \\
\hline rs200131 & Forward: AAGTCGATCGTTAGGGCAAReverse: GTGACTTAGGCCAATGAAA & 302 \\
\hline rs102312 & Forward: AGGCAAATTCGATCGTAGCTAGReverse: TGCTGTAGCTAGCTGATCG & 381 \\
\hline
\end{tabular}

Table II Probe sequences and product sizes of ligase reaction for different polymorphisms of the Klotho gene.

\begin{tabular}{|l|l|l|c|}
\hline Polymorphism & Probe & Probe sequence $\left(5^{\prime}-3^{\prime}\right)$ & Product (bp) \\
\hline rs192031 & $\begin{array}{l}\text { rs192031 } \\
\text { Ars192031- }\end{array}$ & $\begin{array}{l}\text { P-ACGTAGCTAGCTAGTTTTTTTTTTTTTTTTTTT-FAM } \\
\text { TTTTTTTTTTTTTTTACCCATTTTTTTTTAT } \\
\text { TTTTTTTTTTTTTTGCGACGAGCATTTTTTTTAAA }\end{array}$ & 124 \\
\hline rs200131 & $\begin{array}{l}\text { rs192031 } \\
\text { rs192031-C } \\
\text { rs192031-T }\end{array}$ & $\begin{array}{l}\text { P-AGCCATGCACCCAATTTTTTTTTTTTTTTTTTT-FAM } \\
\text { TTTTTTTTTTTTTTTTTTTTTTTTCGTAGCTAAAC } \\
\text { TTTTTTTTTTTTTTTTTTTTTTTTACGATCGATG }\end{array}$ & 115 \\
\hline rs102312 & $\begin{array}{l}\text { rs102312 } \\
\text { s102312-Ar }\end{array}$ & $\begin{array}{l}\text { P-ACGGGATGCCATTTTTTTTTTTTTTTTTTT-FAM } \\
\text { TTTTTTTTTTTTTTTTTTTTTTTTTTTTTTTTTTTTTTGGGCGAGA }\end{array}$ & 108 \\
\hline
\end{tabular}

Primer sequences of each polymorphism were shown in Table I. The reaction system of PCR $(20 \mu \mathrm{L})$ included $2.0 \mu \mathrm{L}$ of DNA template, $10.0 \mu \mathrm{L}$ of $2 \times$ mix, 0.4 $\mu \mathrm{L}$ of forward primer, $0.4 \mu \mathrm{L}$ of reverse primer, and $7.2 \mu \mathrm{L}$ of $\mathrm{dd} \mathrm{H}_{2} \mathrm{O}$. PCR amplification was performed under the following conditions: $95^{\circ} \mathrm{C}$ for $120 \mathrm{~s}, 35$ cycles of $94^{\circ} \mathrm{C}$ for $30 \mathrm{~s}, 57^{\circ} \mathrm{C}$ for $90 \mathrm{~s}$ and $72{ }^{\circ} \mathrm{C}$ for $60 \mathrm{~s}$, followed by extension at $72{ }^{\circ} \mathrm{C}$ for $10 \mathrm{~min}$. Subsequently, agarose gel electrophoresis was utilized to detect the amplification of gene fragments.

\section{Ligase detection reaction}

The upstream and downstream probes used in this reaction were designed and synthesized by BGI. The upstream probe was modified by phosphorylation at the 5 '-terminal region to prepare a probe mixture with a concentration of $12.5 \mathrm{pmol} / \mu \mathrm{L}$. Ligase detection reaction system $(3.05 \mu \mathrm{L})$ was composed of $0.05 \mu \mathrm{L}$ of ligase, $1 \mu \mathrm{L}$ of buffer, $1 \mu \mathrm{L}$ of PCR product, and $1 \mu \mathrm{L}$ of probe mixture. PCR amplification was carried out under the following conditions: $95^{\circ} \mathrm{C}$ for $120 \mathrm{~s}, 94^{\circ} \mathrm{C}$ for $15 \mathrm{~s}$ and $50{ }^{\circ} \mathrm{C}$ for $25 \mathrm{~s}, 30$ cycles in total. After that, the concentration was measured using the ultraviolet spectrophotometer. Subsequently, BGI was commissioned to sequence and analyze the target gene. All data were analyzed using Gene Mapper (Table II).

\section{Statistical analysis}

Statistical Product and Service Solutions (SPSS) 22.0 software (IBM, Armonk, NY, USA) was applied for statistical analysis. Enumeration data were expressed by frequency and percentage, and measurement data were presented as meantstandard deviation. The genotype frequency in the sample was calculated and tested using the Hardy-Weinberg equilibrium formula. The chi-square test was used for multiple comparisons of enumeration data. Besides, $t$-test and analysis of variance were utilized for measurement data. $\mathrm{P}<0.05$ indicated that the difference was statistically significant.

\section{Results}

Comparisons of clinical baseline data between $\mathrm{Cl}$ group and control group

As shown in Table III, blood glucose and systolic blood pressure were obviously increased, but highdensity lipoprotein cholesterol (HDL-C) significantly declined in $\mathrm{Cl}$ group compared with those in control group $(\mathrm{P}<0.05)$.

Comparison of Klotho protein levels in peripheral blood between $\mathrm{Cl}$ group and control group

As shown in Figure 1, the expression level of Klotho in the peripheral blood of patients was markedly reduced in $\mathrm{Cl}$ group in comparison with that 
Table III Comparisons of clinical data between $\mathrm{Cl}$ group and control group.

\begin{tabular}{|l|c|c|c|}
\hline Index & Control group & $\mathrm{Cl}$ group & $\mathrm{P}$ \\
\hline $\begin{array}{l}\text { Triglyceride } \\
\text { (mmol/L) }\end{array}$ & $1.75 \pm 0.28$ & $1.81 \pm 0.21$ & 0.112 \\
\hline $\begin{array}{l}\text { Total cholesterol } \\
\text { (mmol/L) }\end{array}$ & $4.88 \pm 0.48$ & $4.91 \pm 0.25$ & 0.341 \\
\hline $\mathrm{HDL}-\mathrm{C}(\mathrm{mmol} / \mathrm{L})$ & $1.28 \pm 0.11$ & $1.14 \pm 0.49$ & 0.003 \\
\hline $\begin{array}{l}\text { LDL-C (mmol/L) } \\
\text { Blood glucose } \\
\text { (mmol/L) }\end{array}$ & $2.99 \pm 0.28$ & $3.02 \pm 0.12$ & 0.288 \\
\hline $\begin{array}{l}\text { Systolic blood } \\
\text { pressure (mmHg) }\end{array}$ & $131.92 \pm 4.02$ & $145.03 \pm 6.82$ & 0.000 \\
\hline $\begin{array}{l}\text { Diastolic blood } \\
\text { pressure (mmHg) }\end{array}$ & $80.02 \pm 3.02$ & $84.29 \pm 4.02$ & 0.018 \\
\hline
\end{tabular}

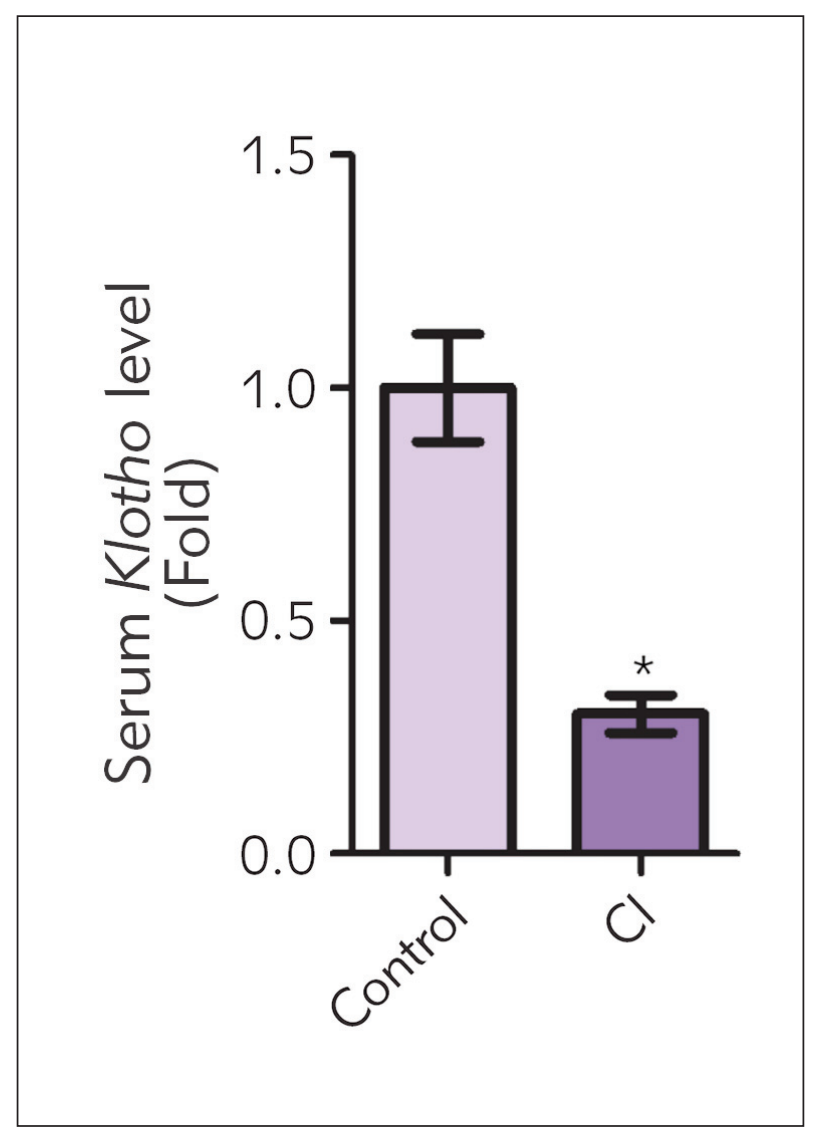

Figure 1 Comparison of Klotho protein levels in peripheral blood between $\mathrm{Cl}$ group and control group. $\mathrm{Cl}$ : cerebral infarction group. Control: healthy control group. ${ }^{\star} \mathrm{P}<0.05$ : a statistical difference vs. control group. in control group $(P<0.05)$, indicating that Klotho might be involved in the occurrence and development of $\mathrm{Cl}$.

Analysis results of Klotho gene polymorphismsrs192031, rs200131 and rs 102312

The Klotho gene polymorphisms rs192031, rs200131 and rs102312 in $\mathrm{Cl}$ group and control group were cleaved by BSTU I restriction enzyme, manifesting that polymorphism rs192031 had two alleles $(\mathrm{A}$ and $\mathrm{T})$ and three genotypes (AA, AT and TT), rs200131 had two alleles (C and T) and three genotypes (CC, CT and TT), and rs102312 had two alleles $(A$ and $C)$ and three genotypes $(A A, A C$ and $\mathrm{CC}$.

\section{Results of Hardy-Weinberg equilibrium test}

The linkage disequilibrium test results of different Klotho gene polymorphisms were tested using the Hardy-Weinberg equilibrium formula. As shown in Table $N, r^{2}<0.33$ was detected between groups of polymorphisms, indicating the conformity of polymorphisms with the equilibrium test between groups.

Associations of Klotho gene polymorphisms with $\mathrm{Cl}$

The genotype frequencies of each gene polymorphism in the two groups were shown in Table $V$. The polymorphism rs 192031 was remarkably related to the occurrence of $\mathrm{Cl}(\mathrm{P}<0.05)$, while rs200131 and rs102312 were not correlated with $\mathrm{Cl}(\mathrm{P}>0.05)$.

Table IV Results of linkage equilibrium test for the Klotho gene polymorphisms between groups.

\begin{tabular}{|c|c|c|c|}
\hline Polymorphism & $r^{2}$ & & \\
\hline & rs192031 & rs200131 & rs102312 \\
\hline rs192031 & - & 0.012 & 0.108 \\
\hline rs200131 & 0.012 & - & 0.221 \\
\hline rs102312 & 0.108 & 0.221 & - \\
\hline
\end{tabular}

Table V Distribution of different genotypes of Klotho gene polymorphisms and $\mathrm{Cl}$.

\begin{tabular}{|l|c|c|c|c|c|c|c|c|c|}
\hline \multirow{2}{*}{ Group } & \multicolumn{3}{|c|}{ rs192031 } & \multicolumn{3}{c|}{ rs200131 } & \multicolumn{3}{c|}{ rs102312 } \\
\cline { 2 - 9 } & AA & AT & TT & CC & CT & TT & AA & AC & CC \\
\hline Cl & $10.1 \%$ & $50.9 \%$ & $39.0 \%$ & $20.1 \%$ & $48.0 \%$ & $30.0 \%$ & $20.1 \%$ & $50.9 \%$ & $29.0 \%$ \\
\hline Control & $24.0 \%$ & $51.2 \%$ & $24.8 \%$ & $22.8 \%$ & $46.0 \%$ & $31.2 \%$ & $19.3 \%$ & $51.2 \%$ & $29.5 \%$ \\
\hline$C^{2}$ & 1.661 & & & 0.499 & & & 0.717 & & \\
\hline P & 0.032 & & & 0.221 & & & 0.610 & & \\
\hline
\end{tabular}


Table VI Distribution of alleles of Klotho gene polymorphisms and $\mathrm{Cl}$.

\begin{tabular}{|l|c|c|c|c|c|c|}
\hline Group & \multicolumn{2}{|c|}{ rs192031 } & \multicolumn{2}{c|}{ rs200131 } & \multicolumn{2}{c|}{ rs102312 } \\
\hline & $\mathrm{A}$ & $\mathrm{T}$ & $\mathrm{C}$ & $\mathrm{T}$ & $\mathrm{C}$ \\
\hline $\mathrm{Cl}$ & $30.00 \%$ & $70.00 \%$ & $70.21 \%$ & $29.79 \%$ & $45.23 \%$ & $54.77 \%$ \\
\hline Control & $82.11 \%$ & $17.89 \%$ & $72.22 \%$ & $27.78 \%$ & $42.08 \%$ & $57.92 \%$ \\
\hline $\mathrm{C}^{2}$ & 1.432 & & 0.782 & & 0.644 & \\
\hline $\mathrm{P}$ & 0.001 & & 0.114 & & 0.412 & \\
\hline
\end{tabular}

Table VII Correlation analysis of TT genotype of Klotho gene polymorphism rs192031 and clinical parameters of Cl.

\begin{tabular}{|l|c|c|c|}
\hline \multirow{2}{*}{ Index } & \multicolumn{2}{|c|}{ TT genotype } & \multirow{2}{*}{ P } \\
\cline { 2 - 3 } & $\mathrm{Cl}$ & $49 \pm 10$ & 0.231 \\
\hline Age & $48 \pm 7$ & $1.85 \pm 0.18$ & 0.302 \\
\hline Triglyceride, (mmol/L) & $1.88 \pm 0.27$ & $4.91 \pm 0.18$ & 0.429 \\
\hline Total cholesterol, (mmol/L) & $4.91 \pm 0.26$ & $1.16 \pm 0.15$ & 0.019 \\
\hline HDL-C, (mmol/L) & $1.33 \pm 0.28$ & $2.98 \pm 0.21$ & 0.192 \\
\hline LDL-C, (mmol/L) & $3.02 \pm 0.15$ & $5.81 \pm 0.47$ & 0.821 \\
\hline Blood glucose, (mmol/L) & $6.22 \pm 0.56$ & $134.83 \pm 5.22$ & 0.001 \\
\hline Systolic blood pressure, $(\mathrm{mmHg})$ & $142.11 \pm 4.20$ & $80.01 \pm 6.92$ & 0.231 \\
\hline Diastolic blood pressure, $(\mathrm{mmHg})$ & $82.11 \pm 5.92$ & & 0 \\
\hline
\end{tabular}

\section{Association of Klotho alleles with $\mathrm{Cl}$}

According to the genotype frequencies of each polymorphism in the two groups (Table VI), the polymorphism rs192031 was obviously associated with occurrence of $\mathrm{Cl}(\mathrm{P}<0.05)$, while rs200131 and rs102312 had no relations with $\mathrm{Cl}(\mathrm{P}>0.05)$.

Correlations of TT genotype of Klotho gene polymorphism rs 192031 with clinical parameters of $\mathrm{Cl}$

The further research revealed that the systolic blood pressure and HDL-C were notably higher in $\mathrm{Cl}$ patients with TT genotype of Klotho gene polymorphism rs192031 than those in control group $(\mathrm{P}<0.05)$ (Table VII).

\section{Discussion}

$\mathrm{Cl}$ is a cerebrovascular disease caused by cerebral blood supply disorders, which is characterized by high morbidity and high mortality, seriously threatening people's lives (10). $\mathrm{Cl}$ can be caused by multiple factors, especially atherosclerosis. Atherosclerotic $\mathrm{Cl}$ is a multi-source disease resulting from the combined action of genetic and environmental factors. Atherosclerosis can lead to stenosis, occlusion and thrombosis of the blood vessel cavity, or the shedding of unstable plaques can result in $\mathrm{Cl}$ (11). Therefore, further elucidating the genetic mechanism of $\mathrm{Cl}$ occurrence is of important significance for the early prevention and precise treatment of $\mathrm{Cl}$.

Previous studies have shown that the polymorphisms of multiple genes are potentially correlated with the occurrence and prognosis of $\mathrm{Cl}$. The allele frequency of APOE 4 is notably higher in $\mathrm{Cl}$ patients than that in healthy controls (12). Tissue inhibitors of metalloproteinases (TIMPs), as endogenous inhibitors of matrix metalloproteinases, participate in the normal cellular processes and the occurrence and progression of atherosclerosis. A study indicated that there is a strong linkage disequilibrium between 1296T/C and -915A/G of TIMP gene, and people with $\mathrm{TC}+\mathrm{CC}$ genotype are 1.8 times more likely to suffer mixed carotid plaque than those with TT genotype (13). The certain association of Klotho gene polymorphisms with the occurrence and progression of $\mathrm{Cl}$ was revealed in this study.

In animal models, a broad phenotype similar to the aging phenotype will be caused by suppressing the Klotho gene, including atherosclerosis, ectopic calcification, infertility, skin atrophy and severe hypoglycemia, while the overexpression of Klotho gene increases the overall life span of guinea pigs by 20$30 \%$ (14). The human Klotho gene is located on chromosome 13 and can be expressed as a secretory Klotho protein by variable cleavage of the third exon. The anchored Klotho protein is mainly present in the distal convoluted tubules of the kidney and the choroid plexus of the brain, but it can be processed 
and released into the blood after translation, dissociating outside the cells and playing a hormone-like role (15). Klotho gene has 6 SNPs in exon 2 and flanking regions, and such polymorphisms are closely related to the occurrence and progression of cardiocerebrovascular diseases (16). The content of serum Klotho is higher in patients with a history of myocardial infarction but no history of coronary artery disease or stroke, but the haplotype of Klotho is not correlated with the above variables (17). Klotho gene polymorphism may be a genetic risk factor for atherosclerotic coronary artery disease rather than vasospasm angina pectoris in the Japanese population. Specifically, a higher ratio of $A$ genotype of the Klotho gene polymorphism G-395A was observed in patients with coronary heart disease than that in healthy controls (18). The correlation between polymorphisms (rs192031, rs200131 and rs102312) in the promoter region of Klotho and $\mathrm{Cl}$ occurrence in the Han population was analyzed in this study. The protein was extracted from the peripheral blood of healthy people undergoing physical examination and $\mathrm{Cl}$ patients. First, the results of ELISA revealed that the expression of Klotho protein was lower in the peripheral blood of patients in $\mathrm{Cl}$ group $(\mathrm{P}<0.05)$.

\section{References}

1. Rabinstein AA, Friedman JA, Weigand SD, McClelland RL, Fulgham JR, Manno EM, et al. Predictors of cerebral infarction in aneurysmal subarachnoid hemorrhage. Stroke 2004; 35(8): 1862-6.

2. Fletcher AP, Alkjaersig N, Lewis M, Tulevski V, Davies A, Brooks JE, et al. A pilot study of urokinase therapy in cerebral infarction. Stroke 1976; 7(2): 135-42.

3. Zhang Y, Liu G, Wang Y, Su Y, Leak RK, Cao G. Procalcitonin as a Biomarker for Malignant Cerebral Edema in Massive Cerebral Infarction. Sci Rep 2018; 8(1): 993.

4. Drake FH, Dodds RA, James IE, Connor JR, Debouck C, Richardson $S$, et al. Cathepsin K, but not cathepsins B, L, or $\mathrm{S}$, is abundantly expressed in human osteoclasts. J Biol Chem 1996; 271(21): 12511-6.

5. Luo L, Zhu M, Zhou J. Association between CTSS gene polymorphism and the risk of acute atherosclerotic cerebral infarction in Chinese population: a case-control study. Biosci Rep 2018; 38(6): BSR20180586.

6. Li Y, Chen F, Wei A, Bi F, Zhu X, Yin S, et al. Klotho recovery by genistein via promoter histone acetylation and DNA demethylation mitigates renal fibrosis in mice. J Mol Med (Berl) 2019; 97(4): 541-52.

7. Jerin A, Mosa OF, Kališnik JM, Žibert J, Skitek M. Serum Klotho as a marker for early diagnosis of acute kidney injury after cardiac surgery. J Med Biochem 2020; 39 (2): 133-9.

8. Mazucanti CH, Kawamoto EM, Mattson MP, Scavone C, Camandola S. Activity-dependent neuronal Klotho en-
Subsequently, the target polymorphisms were genotyped to record the distribution of genotype and allele frequencies in different groups. The results indicated that there were significant correlations between the Klotho gene polymorphism rs192031 and its genotypes and the occurrence of $\mathrm{Cl}(\mathrm{P}<0.05)$. People with AT genotype were more likely to suffer $\mathrm{Cl}$ than those with AA or TT genotype. The polymorphisms rs200131 and rs102312 and their genotypes had no remarkable associations with $\mathrm{Cl}$ occurrence $(\mathrm{P}>0.05)$.

\section{Conclusions}

In conclusion, this study illuminates for the first time that the Klotho gene polymorphism rs192031 was potentially associated with the occurrence of $\mathrm{Cl}$, while polymorphisms rs200131 and rs102312 and their genotypes were not related to the onset of $\mathrm{Cl}$.

Acknowledgements. No

\section{Conflict of interest statement}

The authors reported no conflict of interest regarding the publication of this article.

hances astrocytic aerobic glycolysis. J Cereb Blood Flow Metab 2019; 39(8): 1544-56.

9. Long FY, Shi MQ, Zhou HJ, Liu DL, Sang N, Du JR. Klotho upregulation contributes to the neuroprotection of ligustilide against cerebral ischemic injury in mice. Eur J Pharmacol 2018; 820: 198-205.

10. Brott T, Tomsick T, Feinberg W, Johnson C, Biller J, Broderick J, et al. Baseline silent cerebral infarction in the Asymptomatic Carotid Atherosclerosis Study. Stroke 1994; 25(6): 1122-9.

11. Kim J, Song TJ, Song D, Lee HS, Nam CM, Nam HS, et al. Serum alkaline phosphatase and phosphate in cerebral atherosclerosis and functional outcomes after cerebral infarction. Stroke 2013; 44(12): 3547-9.

12. Jin ZQ, Fan YS, Ding J, Chen M, Fan W, Zhang GJ, et al. Association of apolipoprotein E 4 polymorphism with cerebral infarction in Chinese Han population. Acta Pharmacol Sin 2004; 25(3): 352-6.

13. Zheng Z, He X, Zhu M, Jin X, Li C, Zhu F, et al. Tissue inhibitor of the metalloproteinases-3 gene polymorphisms and carotid plaque susceptibility in the Han Chinese population. Int J Neurosci 2018; 128(10): 9207.

14. Yamamoto M, Clark JD, Pastor JV, Gurnani P, Nandi A, Kurosu $\mathrm{H}$, et al. Regulation of oxidative stress by the antiaging hormone klotho. J Biol Chem 2005; 280(45): 38029-34. 
15. Nagai T, Yamada K, Kim HC, Kim YS, Noda Y, Imura A, et al. Cognition impairment in the genetic model of aging klotho gene mutant mice: a role of oxidative stress. Faseb J 2003; 17(1): 50-2.

16. Shimada T, Takeshita Y, Murohara T, Sasaki K, Egami K, Shintani $S$, et al. Angiogenesis and vasculogenesis are impaired in the precocious-aging klotho mouse. Circulation 2004; 110(9): 1148-55.
17. Paula RS, Souza VC, Machado-Silva W, Almeida BR, Daros AC, Gomes L, et al. Serum Klotho (but not haplotypes) associate with the post-myocardial infarction status of older adults. Clinics (Sao Paulo) 2016; 71(12): 72532.

18. Jo SH, Kim SG, Choi YJ, Joo NR, Cho GY, Choi SR, et al. KLOTHO gene polymorphism is associated with coronary artery stenosis but not with coronary calcification in a Korean population. Int Heart J 2009; 50(1): 23-32.

Received: October 11, 2021

Accepted: November 01, 2021 